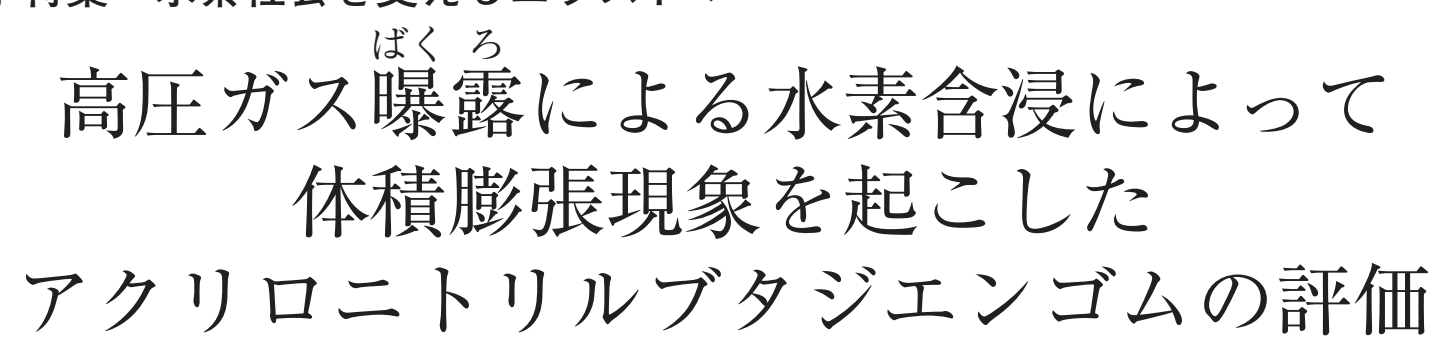

藤 原 広 匡

\title{
Analysis of Acrylonitrile Butadiene Rubber (NBR) Expanded with Penetrated Hydrogen Due to High-pressure Hydrogen Exposure
}

Hirotada FUJIWARA (Research Center for Hydrogen Industrial Use and Storage, Kyushu University, 744 Motooka, Nishi-ku, Fukuoka-city, Fukuoka 819-0395, Japan) fujiwara.hirotada.835@m.kyushu-u.ac.jp

Influence of high-pressure hydrogen exposure on rubber materials was analyzed using typical rubber models of vulcanized acrylonitrile butadiene rubber(NBR); unfilled(NBR-NF), filled with carbon black(NBR-CB)or silica(NBR-SC). Hydrogen penetrated in rubber affects volume change larger in the order of NBR-CB $<\mathrm{NBR}-\mathrm{SC}<\mathrm{NBR}-\mathrm{NF}$. The late hydrogen elimination in NBR-CB was explained by hydrogen adsorption on carbon black. Deterioration and recovery of elastic modulus is not due to the restraint of rubber molecular mobility but the volume expansion. Cross-linkage was not affected by the repetition of hydrogen exposure. Infrared spectroscope(IR)and solid state NMR showed no chemical structural change such as hydrogenation or chain scissions. Pulsed NMR data suggested that the change of relaxation time $\left(T_{2}^{S}\right)$ ratio observed only in NBR-SC was caused by detachment or destruction of filler-gel interface or between silica aggregations. In NBR-CB, the bound rubber structure may have stronger interaction to cause no damage of fatigue by the exposure-repetition. Solid state NMR analysis for states of hydrogen penetrated in rubber revealed the existence of hydrogen in two different states; one adsorbed on rubber matrix, the other free hydrogen having no interaction with rubber matrix, which affects the volume expansion and causes deterioration.

(Received on July 1, 2016)

Key Words : High-pressure Hydrogen Gas, Acrylonitrile Butadiene Rubber(NBR), Filled Rubber, Penetration, Adsorption, NMR

\section{1. はじめに}

大気中の炭酸ガス濃度上昇に伴う地球温暖化や化石資源 の枯渇等, 環境問題やエネルギー供給問題が顕在化してき ており，水素を基盤としたエネルギー社会の実現に関心が 集まりつつある ${ }^{1)}$. 水素はクリーンエネルギー源であるこ とに加え, 化石燃料以外に再生可能エネルギーからの製造 も可能なため, エネルギー供給源の多様化にも寄与する. 国内では家庭用燃料電池や水素燃料電池車 (FCV) が市 販化され, 普及しつつあり, 筆者も先日のゴム協会年次大 会会場前で一般人の方がFCVを運転されている姿を目に した.ここで言う水素は二次エネルギーで有り，一次エネ ルギーや再生可能エネルギーから製造した水素を水素分子
などの形で運搬・貯蔵し必要に応じて電力に戻すエネルギ ーキャリアとして使用する形態を指す。水素分子として蓄 える際, 高いエネルギー密度を確保する必要が有り, 高圧 状態の水素を使用する事になる。具体的には70 MPaの公 称使用圧力 (最高充填圧力は公称使用圧力の $5 / 4$ 倍の 87.5 $\mathrm{MPa}$ ）での使用が求められつつある ${ }^{2)}$. その際，水素を安

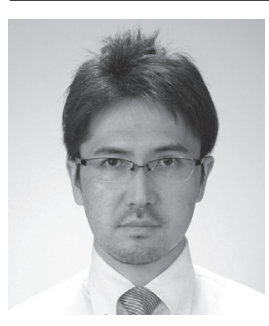

藤原 広匡; 九州大学水素材料先端科学研究セン夕 一高分子材料研究部門 ( 西区元岡 744 九州大学 HY10). 平成 16 年 3 月 埼 玉工業大学物質化学工学専攻 博士後期課程終了 (工博)。化学メーカー勤務後 平成 19 年 12 月 独立 行政法人産業技術総合研究所, 平成 24 年 12 月 九 州大学水素エネルギー国際研究センター（特任准教 授), 平成 25 年 4 月 九州大学水素材料先端科学研 究センター (准教授) 現在に至る。専門は高分子化 学, 高分子合成. 日本ゴム協会九州支部幹事, 水素 機器用エラストマー材料研究分科会書記. 
定かつ, 安全に使用できる環境の整備が不可欠であり, 高 圧水素ガス製造および貯蔵・充填施設などの信頼性や安全 性の確立が求められる.さらに材料の低コスト化を進める ためにも, 高圧水素環境に曝露された際の材料変化を把握 し，より耐久性の高い材料設計を行う事が求められる.

高圧水素ガスのシール用ゴム O-リングには高圧水素条 件下での使用に対し高い耐久性およびシール性が要求され る.ゴム材料は高圧水素曝露によりゴムに溶解（後に述べ るが, あくまで水素が浸入した状態で, 溶媒和した溶解現 象とは異なるため, 今後は含浸と表記する）によりブリス 夕破壊やはみ出し・座屈破壊が生じる事を既に報告してい $3^{3)}$.

当研究グループでは，ゴム材料が高圧水素にさらされた 際の影響を評価するための標準配合ゴムとして, 配合組成 を開示可能かつ, 配合剂の影響を切り分けて議論できるよ うに可能な限り単純な配合を提案している ${ }^{3)}$. 本稿では, このモデル配合ゴムとして作製したシリカ（SC）および カーボンブラック（CB）配合硫黄架橋 NBR を高圧水素に さらした際の水素含浸による体積膨張がゴム弾性に及ぼす 影響について検討した結果について述べる ${ }^{4)}$. また, 固体 NMR 活用し, 含浸水素の状態解析と体積膨張の関係を 解析・評価した結果を紹介する ${ }^{5-7)}$.

\section{2. ゴム試験材料配合と実験法}

当研究グループではいくつかのモデル配合ゴムを使用す ることを決めており，本稿では表 1 に示す，5種のゴム材 料試験片を用いた。

高圧ガス水素曝露実験は九州大学水素材料先端科学研究 センター保有の “高圧ガス曝露容器”内にゴム試験片を入 れ, 市販のガスボンベから供給される水素ガスを昇圧機で 加圧し, 最大で $100 \mathrm{MPa}$ (ゲージ圧）の水素に $30{ }^{\circ} \mathrm{C}$ の環 境でさらした，曝露後試験片の体積測定は，（株）キーエ ンス製 2 次元寸法測定器 TM-3000/TM-065を使用し, 30 ${ }^{\circ} \mathrm{C}$ に保温されたサンプルの影の面積の平方根の三乗を見か け体積として経時測定し, 初期体積に対する規格值で表記 している. 試験片中の含浸水素量測定には（株）ジェイ・ サイエンス・ラボ製, 鋼材中水素測定システムTDA JSH201 を使用している. 水素曝露後の試験片を $30{ }^{\circ} \mathrm{C}$ に温調
した電気炉に入れ，アルゴンキャリアー中に拡散した水素 を5分間隔でガスクロマトグラフィーへ導入し定量するこ で, 取り出し後の試験片中の残存水素量を求めた。弾性率 の測定はアイティー計測制御 DVA-200s 動的粘弾性測定装 置（DMA）を使用し， $30 \mathrm{~mm} \times 2 \mathrm{~mm} \times 1 \mathrm{~mm}$ の短冊状試 験片を歪み量 $0.03 \%$, 周波数 $10 \mathrm{~Hz}$, 測定温度範囲 -130 ${ }^{\circ} \mathrm{C} \sim 200{ }^{\circ} \mathrm{C}$ (昇温速度 $10{ }^{\circ} \mathrm{C} / \mathrm{min}$ ) の条件で測定した. NMRによる一次構造解析およびゴム試験片中に含浸した 水素の解析は超伝導固体 NMR 装置Beuker（株）製 固体 NMR AVANCE III -500MHz を用いた。 ${ }^{1} \mathrm{H}$ NMRによる一 次構造変化の解析は, $2.5 \mathrm{~mm}$ ジルコニアローターに粉末 状ゴムを充填しMAS（マジック角回転）法を使用し, 回 転スピードを $35 \mathrm{kHz}$ としてシングルパルス測定を行った. ${ }^{13} \mathrm{C} \mathrm{NMR}$ による同解析は $4 \mathrm{~mm}$ ジルコニアローターに内径 と同サイズの円柱試験片を装填し, MASスピード $15 \mathrm{KHz}$ でCP (公差分極) 法, およびDD（双極子デカップリン グ）法を用いた。一方, ゴム試験片中に含浸した水素の解 析は $7 \mathrm{~mm}$ ジルコニアローターに内径と同サイズの円柱試

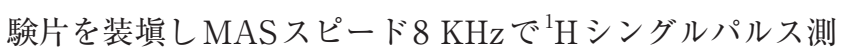
定により行った，緩和時間の評価は反転回復方法を用いて ゴム分子全体の縦緩和時間 $\left(T_{1}\right)$ を計測した。 パルス NMRはBeuker（株）製 TD-NMR mq-20）を用い, ${ }^{1} \mathrm{H} の$ 横緩和時間 $\left(T_{2}\right)$ をSolid-echo 法にて測定し評価した.

\section{3. 体積変化と残存水素量 ${ }^{4}$}

$90 \mathrm{MPa}$ の圧力で 24 時間水素曝露に供された後の NBRNF, NBR-CB50, NBR-SC60の残存水素量と体積の経時変 化を図1-a, 図1-bにそれぞれ示す。脱離プロファイルから 見積もられる単位重量当たりの含浸水素量 ${ }^{8)}$ は本系におい て, シリカ配合ゴムくフィラー未配合ゴムくカーボンブラ ック配合ゴムの順になる。 フィラー単体での水素吸着量を 調べた結果, カーボンブラックは水素を吸着し, シリカは 水素吸着性を示さない. シリカを配合する事で水素含浸す るポリマー重量分率が低下し，未配合ゴムより含浸量が低 下したものと考えられる. 高圧曝露中に圧縮されていたゴ 厶試験片は脱離直後から体積膨張を起こす。体積膨張率は カーボンブラック配合ゴムではフィラーの補強効果で未配 合ゴムに比べて体積膨張が抑制されていることから数值に

Table 1 Chemical composition of specimens

\begin{tabular}{|c|c|c|c|c|c|}
\hline Name & NBR-NF & NBR-CB50 & NBR-CB25 & NBR-SC60 & NBR-SC30 \\
\hline NBR（Nipol 1042:Std） & 100 & 100 & 100 & 100 & 100 \\
\hline MBTS & 1.5 & 1.5 & 1.5 & 1.5 & 1.5 \\
\hline TMTD & 0.5 & 0.5 & 0.5 & 0.5 & 0.5 \\
\hline Stearic Acid & 1 & 1 & 1 & 1 & 1 \\
\hline Zinc oxide & 5 & 5 & 5 & 5 & 5 \\
\hline Sulfur & 1.5 & 1.5 & 1.5 & 1.5 & 1.5 \\
\hline \multirow{2}{*}{\begin{tabular}{ll}
\multirow{2}{*}{ Filler } & HAF Black (ASTM N330) \\
& Silica（Nipsil VN3)
\end{tabular}} & - & 50 & 25 & - & - \\
\hline & - & - & - & 60 & 30 \\
\hline
\end{tabular}



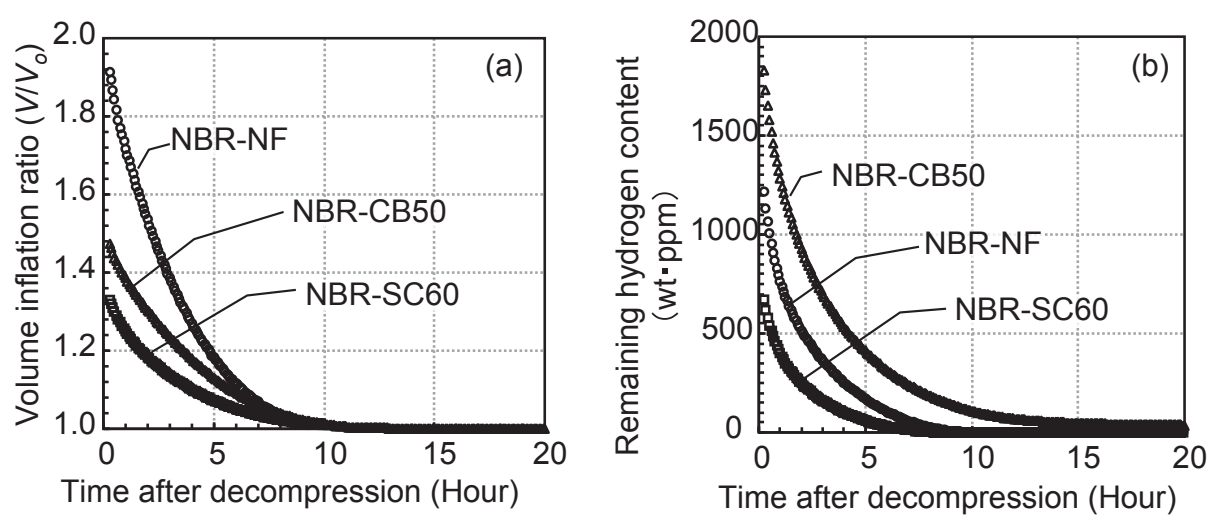

Figure 1 Variance of remaining hydrogen content and volume in the specimens after one time exposure to $90 \mathrm{MPa}$ hydrogen gas at $30{ }^{\circ} \mathrm{C}$ (a: volume, b: remaining hydrogen content)

多少の誤差はあるものの，初期体積に比べNBR-NF； 188\%, NBR-SC $30 ； 173 \%$, NBR-CB50；145\%, NBRSC60；133\%膨張した．時間の経過と共に水素は脱離し， それに伴い体積の収縮が起こり，最終的には完全に元の体 積に戻る．図 2 に残存水素量に対する体積変化を示す。フ イラー未配合ゴムとシリカ配合ゴムでは水素脱離過程にお いて水素量の変化に対する体積変化量は異なるものの，体 積収縮挙動は類似の傾向を示す。一方，カーボンブラック 配合ゴムは残存水素が $100 \mathrm{ppm}$ ぼ残存しているにもか かわらず，元の体積へ収縮し，残存量はカーボンブラック 配合量が多いほど多くなる事が確認されている。ささらにカ ーボンブラックからの水素脱離はゴムマトリックスからの それに比べ遅い事が分かって扮り，体積が収縮した後脱離 する水素はカーボンブラックに吸着した水素と判断した.

\section{4. ゴム弾性率評価}

\section{1 体積膨張時の弾性率の変化 ${ }^{9)}$}

ゴム材料への水素含浸状態での物性変化の確認を行っ た．水素脱離に伴い体積が時事刻々変化する水素含浸状態 の粘弾性挙動を測定するため, 水素曝露後のフィラー未配 合ゴムを $30{ }^{\circ} \mathrm{C}$ の条件に保持し，動的粘弾性測定装置にて 貯蔵弾性率の経時変化を測定した. 測定時の断面積 (True)

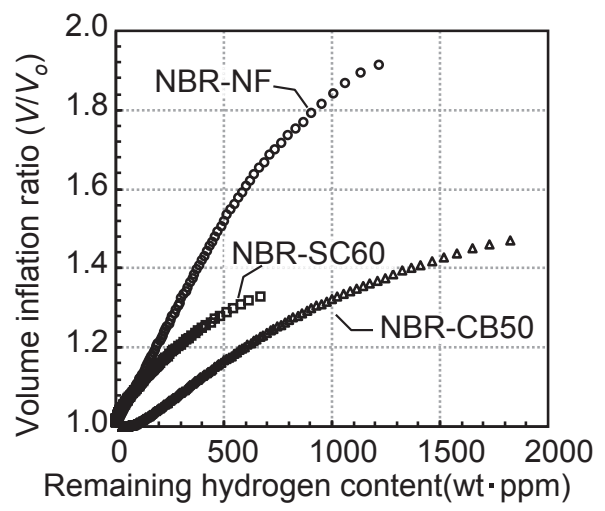

Figure 2 Relationship of volume inflation ratio and remaining hydrogen content
と未曝露時の断面積値（Nominal）をそれぞれもちいて貯 蔵弹性率を求め, 未曝露時の值で規格化した結果を図 3 に 示す，曝露後，残存水素量が多い状態における $E^{\prime}$ (True) は未曝露時に比べ低下し, 水素脱離に伴い初期值に回復し た。一方，残存水素量に対する $E^{\prime}$ (Nominal) は未曝露時 の值を保持している事が分かった．水素曝露により水素が 侵入し体積膨張したゴム試験片の貯蔵弾性率は未曝露時に 比べ低下するが，その原因は水素がゴム分子運動に影響を 与えた結果ではなく，含浸した水素による断面積の増加が 原因であると結論づけた。

\section{2 曝露回数に対する弾性率の変化 ${ }^{4)}$}

繰り返し水素曝露に供された NBRの弾性率の変化を評 価した。この評価は水素含浸量が飽和になった状態と完全 に水素が脱離した状態の履歴が繰り返し加わった際の影響 を評価するのが目的である。 そのため 12 時間水素に曝露 し水素を飽和させた後, 最低でも 2 日間以上 $30{ }^{\circ} \mathrm{C} て ゙$ 水素 脱離を促し次の曝露を行った。 40 サイクル繰り返し水 素曝露した際の貯蔵弾性率 $(E)$ の温度分散測定結果を図 4 に示す。フィラー未配合ゴムおよびカーボンブラック配 合ゴムでは貯蔵弾性率 $\left(E^{\prime}\right)$, 損失弾性率 $\left(E^{\prime \prime}\right)$, 損失正接 $(\tan \delta)$ に曝露前後で顕著な変化は確認されない。一方,

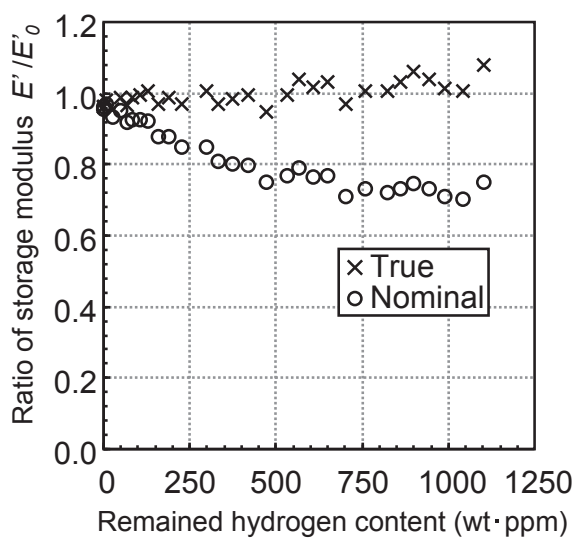

Figure 3 Effect of remained hydrogen content on $E^{\prime}$ (True: cross section of exposed specimen) (Nominal: Cross section of Unexposed specimen) 

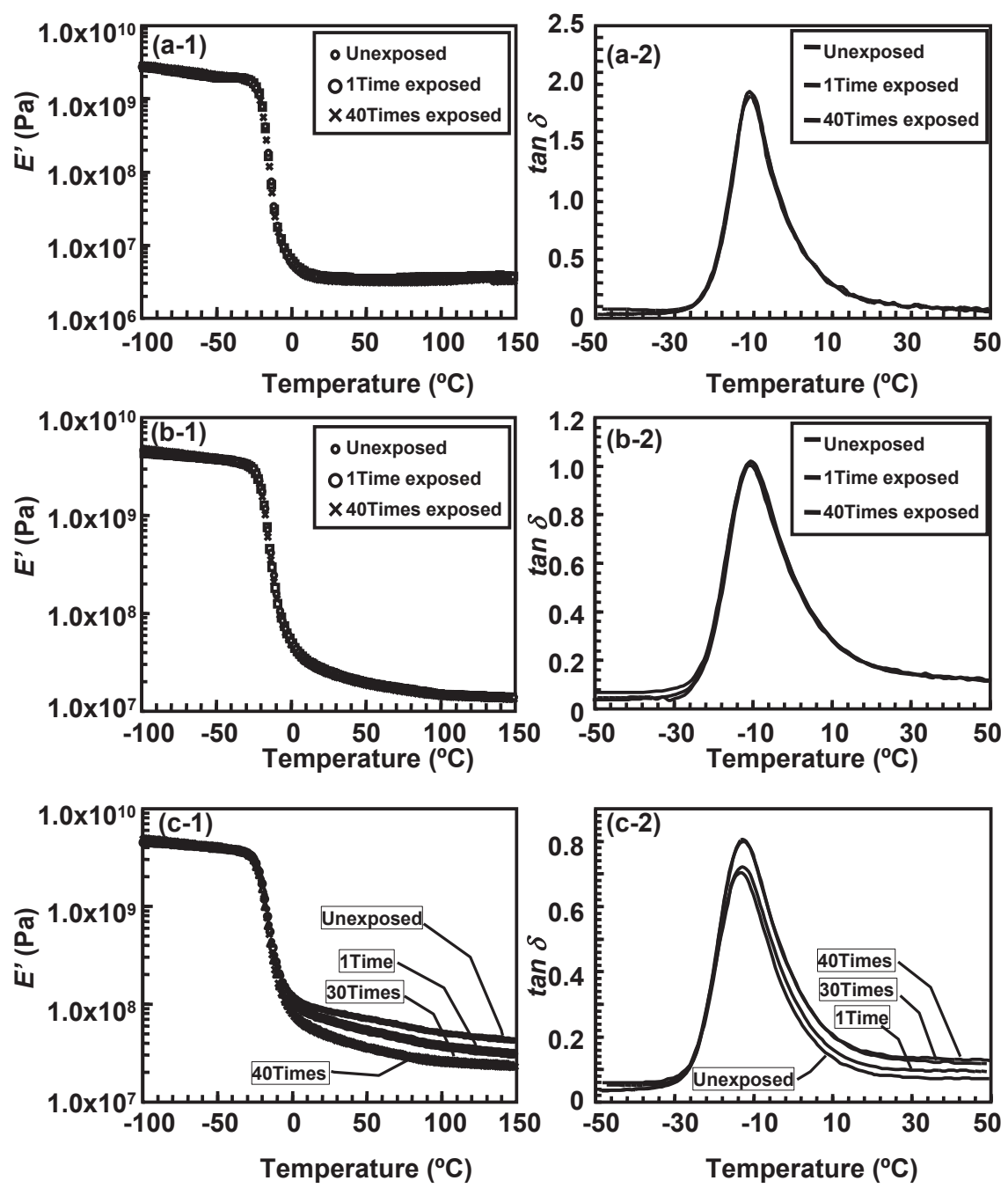

Figure 4 Temperature variance profile of storage modulus $\left(E^{\prime}\right)$ and loss tangent $(\tan \delta)$ of DMA for the specimens unexposed and exposed from 1 time to 30 times and 40 times; (a-1) $E^{\prime}$ of NBR-NF, (a-2) $\tan \delta$ of NBR-NF, (b-1) $E^{\prime}$ of NBR-CB50, (b-2) $\tan \delta$ of NBR-CB50, (c-1) $E^{\prime}$ of NBR-SC50, (c-2) $\tan \delta$ of NBR-SC50.

シリカ配合ゴムでは差が確認されたＮNBR-SC60のE'はー $30{ }^{\circ} \mathrm{C}$ 以下のガラス領域においては曝露前後で変化は見ら れなかったが, ゴム領域では, 曝露回数の増加に伴い $E^{\prime}$ 值の著しい低下が観測され，サイクル数が多いほど低下量 も大きくなる. $\tan \delta$ のピーク温度は若干高温側にシフト し，ピーク幅は広がり，ゴム状平坦領域の值が高くなる傾 向を示した。 ガラス転移温度の変化は確認されなかった。 フィラーの種類と添加量を変化させた試験片の弾性率の変 化を図5に示す. $30{ }^{\circ} \mathrm{C} に お け る E^{\prime}$ の低下率はフィラー未 配合ゴムおよびカーボンブラック配合ゴム共に曝露回数の 増加にともない若干の低下が確認されたが，配合量による 差は確認されない，一方，シリカ配合ゴムの $E^{\prime}$ は曝露回 数の増加に伴い著しく低下し, シリカ配合量の多い試験片 ほど大きく低下することが確認された。また曝露時間の長 さの影響を評価した，全ての試験片において 400 時間と 12 時間それぞれ 1 サイクル曝露された試験片の温度分散挙動 に違いは確認されず，図6に示す通りシリカ配合ゴムのみ 同じ 400 時間曝露されているにもかかわらず曝露回数が多

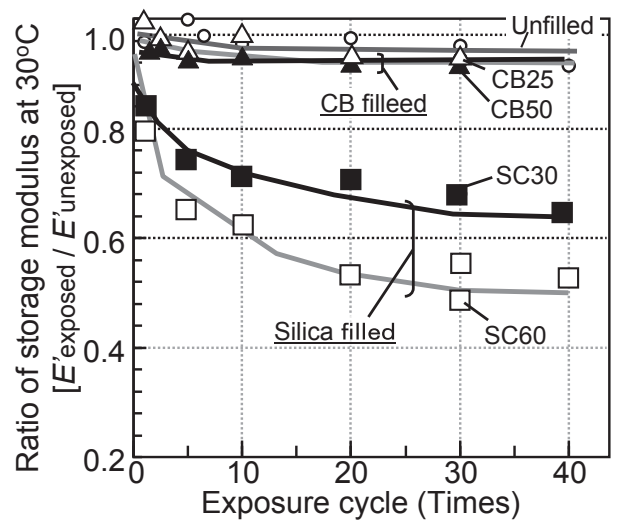

Figure 5 Effect of exposure times from one to 40 on elastic modulus at $30{ }^{\circ} \mathrm{C}$; 0 time means unexposed

い条件での弾性率低下が確認された。よって $E^{\prime} の$ 低下は 曝露時間の長さではなく曝露回数の増加に影響される事が 分かる. $E^{\prime}$ の変化がゴム領域に限られること, フィラー 未配合ゴムでは変化が無いことから本条件で繰り返し曝露 を受けた試験片の架橋密度は変化ないと判断した。 


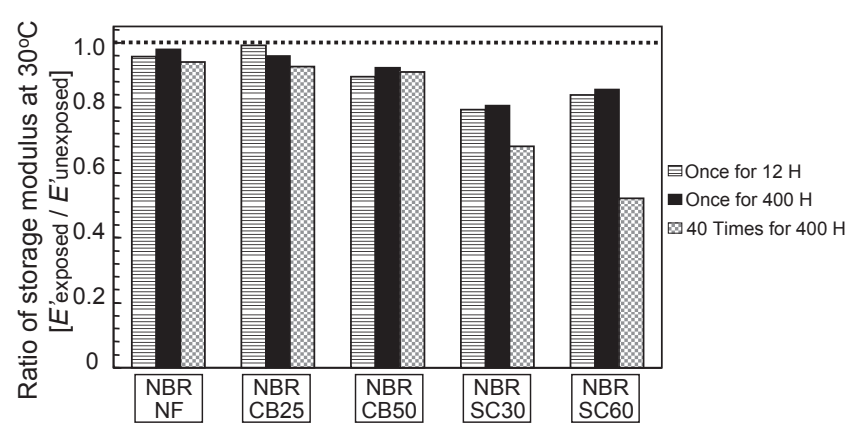

Figure 6 Effect of exposure time length and times (once and forty times). The value at $30^{\circ} \mathrm{C}$ is normalized by $E^{\prime}$ of each samples before exposure.

Dot line means the value does not change before and af ter exposure.

\section{5. 一次構造变化解析 ${ }^{4,6)}$}

繰り返し曝露実験後の試験片における一次構造変化を, 赤外線分光分析法（IR）拈よび核磁気共鳴法（NMR）を 用いて解析した４0回繰り返し水素曝露に供されたフィ ラー未配合ゴムの表層の一次構造解析を多重反射 ATR法 により行った。 シアノ基の吸収強度を基準に各官能基の吸 光度の変化を解析したが, 有意な差は確認されなかった。 また，円柱の試験片を固体 NMR 測定用ジルコニアロー夕 一に挿入し繰り返し水素曝露に供した後 ${ }^{13} \mathrm{C}$ CP-MAS NMR および ${ }^{13} \mathrm{C}$ DD-MAS NMRによるバルクの構造変化 を評価した。図7にNBR-SC60の ${ }^{13} \mathrm{C}$ DD-MAS NMRスペ クトルを示す．比較的ピークの定量性に優れるDD-MAS 測定の結果，繰り返し曝露前後でNBR骨格に帰属される ピーク a）〜 h）の強度に差は確認されなかった。さらに, ${ }^{1} \mathrm{H}$ MASによる水添反応の可能性を評価した，水添反応率 は式（1）に示す ${ }^{1} \mathrm{H}$ NMRスペクトルの不飽和結合由来の メチンプロトン面積（4.8～ $6.0 \mathrm{ppm})$ と飽和結合由来の

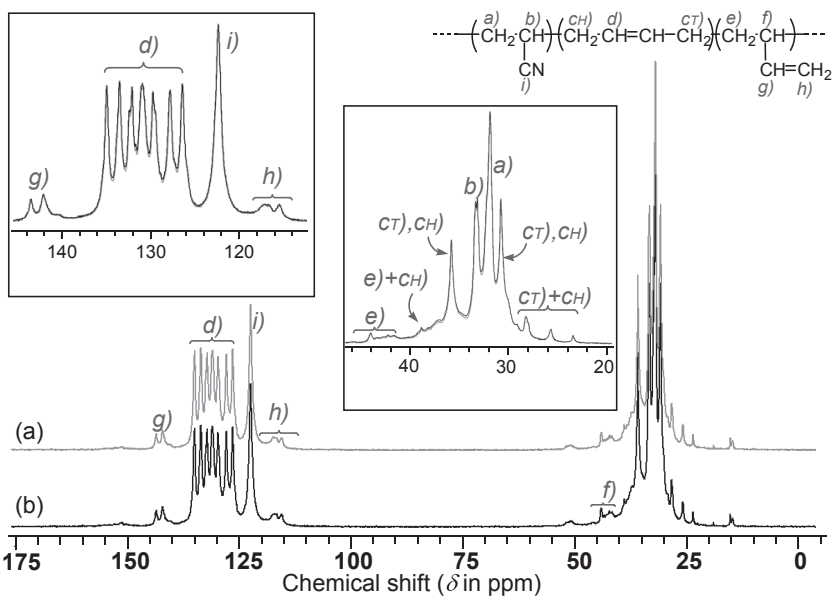

Figure 7 Solid state ${ }^{13} \mathrm{C}$ DD-MAS NMR spectra of SC 60 after 40 cycles of exposure (a) and unexposed (b) with magnified spectra in high $(20 \sim 46 \mathrm{ppm})$ and low $(112 \sim 146$ ppm) magnetic field.
メチレンプロトン面積 $(0.6$ ～ $3.0 \mathrm{ppm})$ の比率 $A$ と $B$ よ り算出した。

$$
D_{H}=100-\frac{\left[\frac{8-5 c_{A C N}}{(2 \alpha+3 \beta)+(8-(4 \alpha+3 \beta))(A / B)}\right]\left(\frac{A}{B}\right)}{1-c_{A C N}} \times \frac{1}{100} \text { (1) }
$$

ここで $D_{\mathrm{H}}(\mathrm{mol} \%)$ は水素添加率, $\mathrm{C}_{\mathrm{ACN}}(\mathrm{mol} \%)$ は $\mathrm{NBR}$ 中のアクリロニトリルのモル分率， $\alpha$ と $\beta$ は 1,4-ブタジエン (cis/trans）と1,2-ブタジエンのモル分率をそれぞれ示す. また，本測定の信頼性を確認するため， $2 \mathrm{~mol} \%$ 相当のポ リオレフィン粉末を共存させ測定を行った。 3 回の測定平 均值を評価したが繰り返し曝露実験後の $D_{\mathrm{H}}$ は未使用の值 より小さく，またポリオレフィン粉末を共存させた際は $D_{\mathrm{H}}$ 值の増加が確認された，以上の評価からは，水添反応 や化学結合の解離, それに伴う不均化や再結合反応, 酸化 反応の痕跡は確認されない。水素は還元性ガスであり，空 気酸化反応は抑制されたと考えた.

\section{6. パルス NMRによるバウンドラバー層の測定 ${ }^{4)}$}

ゴムマトリクスにフィラーを分散させる際の混練り過程 でゴム分子鎖とフィラー界面との相互作用により分子運動 性が低下したバウンドラバー層が形成され，補強性や粘弾 性特性に大きく影響する。このバウンドラバー層の評価に パルスNMRを用いる測定が知られている ${ }^{10,11)}$ 。そこで, パルス NMRを用いSolid-echo法にて横緩和時間 $\left(T_{2}^{H}\right)$ を 測定し, 緩和時間と各緩和時間の成分比から, 繰り返し曝

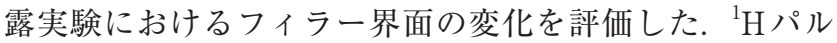
ス NMR測定により得られた自由誘導減衰曲線（FID） は $T_{2}$ の短い成分 $\left(T_{2}^{S}\right)$ と長い成分 $\left(T_{2}{ }^{L}\right)$ の 2 成分で再 現された。フィラー近傍の分子鎖は分子運動性が小さいた め, 短い横緩和時間を示し $T_{2}^{S}$ に帰属される。眓 8 にNBR$\mathrm{NF}, \mathrm{NBR}-\mathrm{CB} 50, \mathrm{NBR}-\mathrm{SC60}$ の水素曝露回数に対する $T_{2}^{S}$ のプロトン比を示す。未配合ゴム及びカーボンブラック配 合ゴムでは曝露回数に関係なくプロトン比は一定の值を示 す. 一方, シリカ配合ゴムは曝露回数の増加に従い $T_{2}^{S}$ の 割合が低下した。見かけ上分子運動が拘束されているポリ

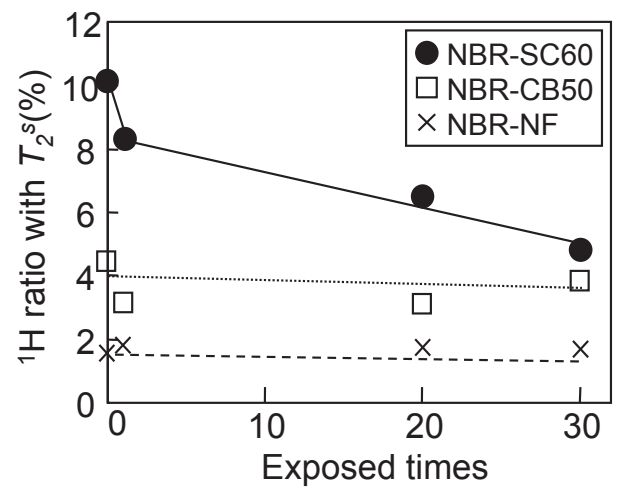

Figure 8 Relation of exposure times from one to 30 and ${ }^{1} \mathrm{H}$ ratio with $T_{2}^{S} ; 0$ time means unexposed 


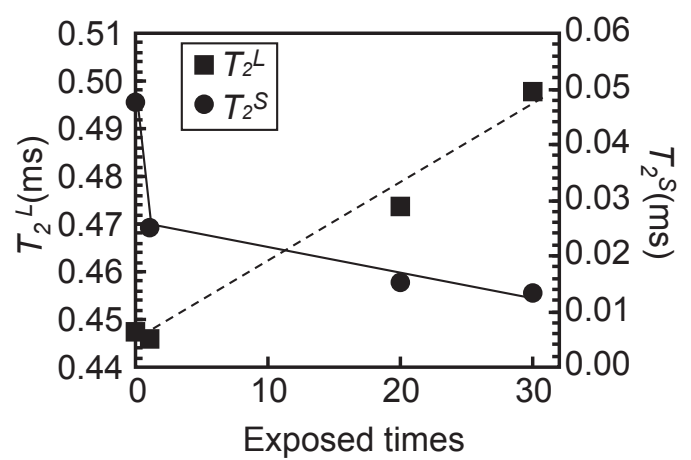

Figure 9 Relation of exposure times from one to 30 and time of $T_{2}^{L}$ and $T_{2}^{S}$ of NBR-SC60; 0 time means unexposed

マー量が低下している事を示している. 図9にNBR-SC60 の各緩和時間を水素曝露回数に対し示す. 曝露回数増加に 伴い $T_{2}^{S}$ 成分はより短くなり, $T_{2}^{L}$ は長くなる.

シリカ配合ゴムのみに観測される曝露回数に対する $T_{2}^{S}$ のプロトン比および緩和時間の変化はDMA で観測された 弾性率の変化に類似の傾向を示した.

観測された $T_{2}^{S}$ はシリカ表面のシラノール基と, NBRの シアノ基の水素結合によって形成される運動性の低い分子 鎖を示し，水素曝露によりこの硬い成分量が低下したと考 える.

図 2 に示したとおり，ゴム材料は水素曝露に伴う水素含 浸によって体積が膨張し, 除圧後, ゴム材料から水素が脱 離することで体積収縮が起こる。この体積の膨張 - 収縮挙 動はゴムの疲労現象の他に, シリカとポリマー界面に弱い 相互作用として形成されたフィラーゲル層，もしくはシリ 力同士の凝集構造を剥離・破壞したと考えられる。シリカ と相互作用している運動性の低い分子鎖のうち，上り強固 に結合した成分が残ることで $T_{2}^{S}$ はより短くなったと推定 した，さらに，シリカ凝集体に取り込まれていた分子運動 性の高いオクルードラバーが放出されることで $T_{2}^{L}$ 成分比 が増加したことも考えられる。 その結果, 弾性率が低下し たと考える，一方，カーボンブラックで形成されたバウン ドラバー層は, シリカによって形成されるものより強固な 相互作用を有し，曝露による疲労を受けても構造を保持し たと考える.

\section{7. 体積膨張を誘発する含浸した水素の状態解析 ${ }^{12)}$}

水素含浸により体積膨張したゴム材料は弾性率の変化以 外にも, Oリング受け部の溝からゴムがはみ出し，き裂が 生じる破壊や溝寸法以上に体積増加することで座屈破壊が 生じ，シール性が担保出来なくなる ${ }^{13)}$ 。よって，シール用 ゴム材料の設計を行う上で含浸水素による加硫ゴムの水素 膨潤挙動を解明することは必須であり，含浸水素の状態解 析が必要となる，そこで，水素曝露によりゴム試験片中に 含浸した水素の状態解析を比較的高感度に定性・定量解析 が可能な測定手法として, 高分解能固体 ${ }^{1} \mathrm{H}$ MAS NMRを

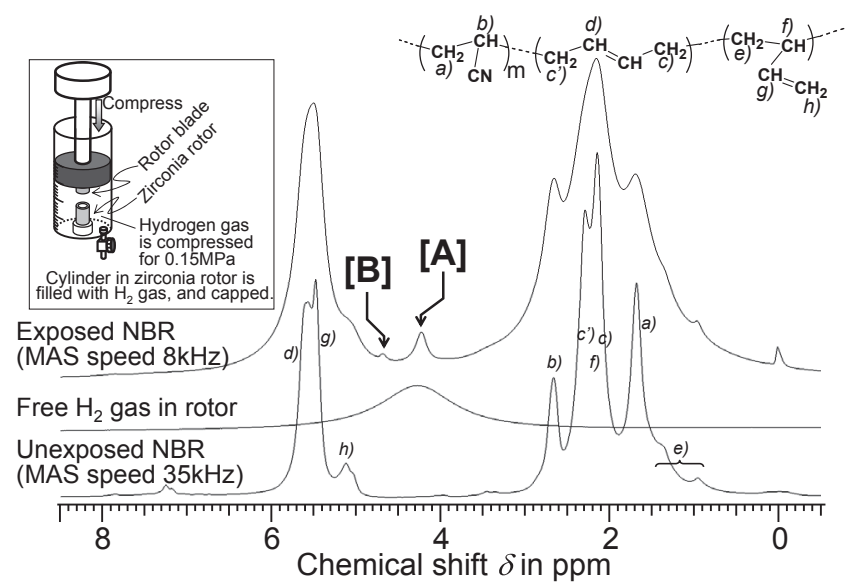

Figure $10 \quad{ }^{1} \mathrm{H}$ NMR spectra of hydrogen exposed specimen with unexposed one and free hydrogen gas. Inset figure represents a hydrogen gas seal system to a Zirconia rotor.

用いて評価した。

固体NMR 測定用のピンホール付きジルコニアローター に円柱形状のフィラー未配合ゴムを装媜した状態で 100 $\mathrm{MPa} \cdot 30{ }^{\circ} \mathrm{C} \cdot 24$ 時間水素曝露に供した. 超伝導固体 NMR 装置を用い $30{ }^{\circ} \mathrm{C} に$ 温調した環境でシングルパルス測定を 行い ${ }^{1} \mathrm{H}$ のペクトルを得た。 図 10 に除圧後 1 時間経過し た時点での ${ }^{1} \mathrm{H}$ NMR スペクトルを水素ガスのスペクトル， および未曝露試験片スペクトルと合わせて示す. NBRに 帰属される a）～h）のピーク以外に $4.2 \mathrm{ppm}$ [A] と 4.6 $\mathrm{ppm}$ 付近 [B] にブロードピークが観測された。曝露後試 験片のDSC 測定を行ったが水の吸熱ピークは観測されな い. 注射器を加工した治具を用意しジルコニアローターの 空間に圧力が $0.15 \mathrm{MPa}$ の水素ガスのみを充填し測定した. 気体水素は $4.2 \mathrm{ppm} に$ にピン回転緩和機構に伴う緩和によ り ${ }^{14)}$ ブロードなピークとして観測された．ゴムからの水 素脱離過程のスペクトル変化を経時測定した結果, 時間の 経過と共に [A］［B］共にピーク強度は減少し最終的に消 滅した。その挙動は別途脱離した水素量をガスクロマトグ ラフィーで観測した結果と酷似した。 サンプルを別のジル コニアローターに移し測定を行うと, 水素脱離に伴う強度 の低下はあるが $[\mathrm{A}][\mathrm{B}]$ のスペクトルは観測される，以 上の結果から $[\mathrm{A}][\mathrm{B}]$ に観測されているプロトンは，ジ ルコニアローターに吸着した水素やローター内に対流した 水素, さらには水分由来の ${ }^{1} \mathrm{H}$ ではなく, バルクのゴム中 に含浸した水素分子由来であると証明された。また，ピー ク [A] [B] は酸化亜鉛及び硫黄を含まない試験片におい ても同じケミカルシフトを有することから, 含浸した水素 は無機添加剤に吸着した水素ではないことも確認された。 つまり, 水素曝露によりゴムマトリックス中へ含浸した水 素は［A］［B］個別のケミカルシフトを示すことから異な った状態で存在している事を意味している.

MAS 回転数の高速化により, ${ }^{1} \mathrm{H}$ 同士の双極子-双極子 相互作用が平均化されることでNBRに帰属されるピーク 


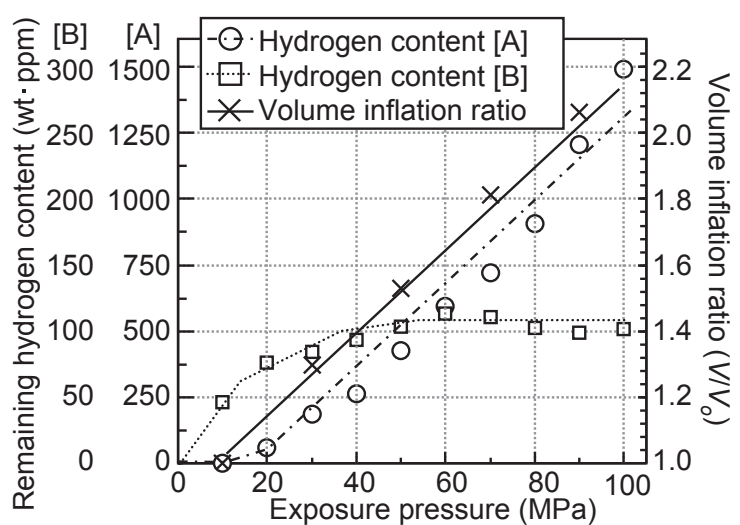

Figure 11 Influence of exposure pressure on the relationship between dissolved hydrogen content and volume expansion ratio one hour after exposure (left-hand axis shows hydrogen content [A] and [B], right-hand axis shows volume expansion ratio).

の線幅は減少するが $[\mathrm{A}]$ と $[\mathrm{B}]$ のピーク線幅は減少し ない。またピーク $[\mathrm{A}]$ は $\mathrm{NBR}$ 由来の ${ }^{1} \mathrm{H}$ と異なる縦緩和 時間 $T_{1}^{H}$ を示し, $\mathrm{NBR}$ 骨格中の ${ }^{1} \mathrm{H}$ とスピン拡散が及ばな い環境に存在している ${ }^{15}$. よって含浸水素のうち $[\mathrm{A}]$ は ポリマーマトリックスと相互作用していない環境に存在 し，ポリマーマトリックスと溶媒和や水素結合をしていな い独立した水素分子と考えた。

図 11 に各圧力で曝露した後 1 時間経過した時点で試料中 に溶解した水素 [A］［B］の濃度とゴム体積膨張の関倸を 示す，曝露圧力の増加に従い，溶解水素の増加が確認でき たが, $10 \mathrm{MPa}$ の曝露圧力では, [A] の水素は確認されな い. 一方, [B] の濃度は, 曝露圧力の増加に従い増加し たが，60 MPa 以上の圧力では変化を示さなかった．各圧 力の水素濃度と体積増加の挙動は水素 [A] と相関がある ことが確認された。

\section{8. ま と め}

本稿では, 高圧水素にさらした際の水素含浸による体積 膨張がゴム弾性に及ぼす影響について検討した結果を報告 した．水素ガスがゴムの化学構造変化を誘発する結果はこ れまで観測されていない.ゴム材料の場合おもに含浸した 水素による体積膨張が引き金となって起こる物理的破壊 や，一度含浸した水素が容易に脱離することで起こる体積 収縮が繰り返されることで機械特性を低下させる事が分か った。

今回報告した試験片はモデル配合ゴムの一部であり，カ
ーボンブラックの種類や架橋密度が水素含浸量や体積変化 率に及ぼす影響，シリカのカップリング剂の影響などに関 しても評価を進めている．また，実際の製品には老化防止 剤や可塑剂等が配合されている場合が多く，体積膨張一収 縮がブルーム現象等に及ぼす影響を評価する必要性もあ り，今後も報告を重ねていく予定である.

\section{謝辞}

この成果は，国立研究開発法人新エネルギー・産業技術 総合開発機構（NEDO）の委託業務の結果得られたもので す.

\section{References}

1 ) Onoue, K.; Murakami, Y.; Sofronis, P.: Int. J Hydrogen Energy, 37, 8123 (2012)

2) ISO Technical Specification 19880-1

3 ) Nishimura, S.: Nippon Gomu Kyokaishi, 86, 360 (2013)

4) Fujiwara, H.; Ono, H.; Nishimura, S.: Int. J Hydrogen Energy, 40, 2025 (2015)

5 ) Nishimura, S.; Fujiwara, H.: Chem. Phys. Lett., 522, 43 (2012)

6 ) Fujiwara, H.; Yamabe, J.; Nishimura, S.: Int. J Hydrogen Ener$g y, 37,8729(2012)$

7 ) Fujiwara, H.: 14-2 NMR kenkyuukai Koen Yoshishu, 15 (2014)

8 ) Yamabe, J.; Nishimura, S.: Int. J Hydrogen Energy, 34, 1977 (2009)

9 ) Fujiwara, H.; Ono, H.; Enomoto, K.; Nishimura, S.: Nippon Gomu Kyokai 26th Elastomer Toronkai Koen Yoshishu, C-24 (2014)

10) Noguchi, T.; Iwabuki, H.: Nippon Gomu Kyokaishi, 76, 178 (2003)

11) Yatsuyanagi, F.; Suzuki, N.; Ito, M.; Kaidou H.: Polymer, 42, $9523(2001)$

12) Fujiwara, H.; Ono, H.; Nishimura, S.: Nippon Gomu Kyokai Nenjitaikai 2014 Koen Yoshishu, P-17 (2014)

13) Yamabe, J.; Koga, A.; Nishimura, S.: Nippon Gomu Kyokaishi, 83, 159 (2010)

14) Harris, R. K.: Nuclear Magnetic Resonance Spectroscopy, Pitman: London (1983)

15) Asano, A.; Takegoshi, K.: "Solid State NMR of Polymers", Chapter 10 (P.367) ,. Ando, I.; Asakura, T.: Elsevier Science Netherlands Amsterdam (1998)

\section{日本語表記参考文献}

3 ）西村伸：日本ゴム協会誌，86，360（2013）

7 ）藤原広匡：14-2 NMR研究会 講演要旨集, 15（2014）

9 ）藤原広匡, 小野皓章, 榎本一之, 西村伸：日本ゴム協会第 26 回 エラストマー討論会講演要旨集 $(2014)$

10）野口徹，岩蕗仁：日本ゴム協会誌，76，178（2003）

12）藤原広匡, 小野皓章, 西村伸：日本ゴム協会年次大会講演要集 2014, P-17 (2014)

13）山辺純一郎, 古賀敦, 西村伸：日本ゴム協会誌，83，159（2010） 